\title{
Epistemological Reform and Embracement of Human Rights. What Can be Inferred from Islamic Rationalistic Maturidite Theology?
}

https://doi.org/10.1515/opth-2019-0030

Received May 05, 2019; accepted August 07, 2019

\begin{abstract}
The authors argue that there is an epistemological crisis of conservative Islamic scholarship and Muslim mind, rooted in the centuries-old confinement of a role for reason within strict limits, and in the disappearance of rationalistic discursive theology ( $\mathrm{kalam}$ ) as a dynamic science. Moreover, epistemological crisis is exemplified by seriously insufficient level of protection of human rights under Sharia when judged by contemporary principles of human rights. This crisis demands a necessity of undertaking epistemological reform, which denotes the incorporation of international standards of human rights and justice into the epistemology and methodology of producing Islamic norms (usul al-fiqh). It is argued that the key epistemological premises of rationalistic Islam, such as acceptance that human reason can find goodness and badness independently from revelation and non-acceptance of ethical voluntarism, may offer a good ground to make epistemological reform, which would induce the Muslims to critically approach and reinterpret the pre-modern religious interpretations and to construct an Islamic legal and ethical system that is appropriate for the context of the 21th century. In the end, reason, being the human capacity for shaping reality in a humane way, is indispensable to read religious sources from a historical-metaphorical point of view.
\end{abstract}

Keywords: epistemological reform, rationalistic Islam, human rights, kalam, Maturidite theology

\section{Introduction: Erosion of pluralism and the need for reform}

Islam is many things; just as there is no single Europe or West, there is no single place or uniform phenomenon called Islam. ${ }^{1}$ Nonetheless, in today's world Islam is regularly associated with the rejection of diversity, pluralism and fundamental human rights, e.g., freedom of choice, freedom of thought and expression, and gender equality. This negative association cannot be blamed merely on the persistence of Orientalist and Islamophobic tendencies. Rather, we argue that the Muslim communities around the world are crippled by a crisis of pluralism and the erosion of pluralist mind and culture. Moreover, they are enfeebled by an inability to produce the religious interpretations that would correspond with the contemporary standards of human rights and justice.

First, all these are manifested in the blind acceptance by a majority of contemporary traditionalist scholars and mainstream conservative Muslims of the whole body of the pre-modern era and distinguished by strict religious exclusivism (in simple terms, exclusive religious doctrine denies acceptance of the salvation beyond its teachings, on the contrary, religious inclusivism accepts that there are more ways than one to salvation) ${ }^{2}$

1 Lawrence, Shattering the Myth, 4.

2 See, for example, Kamali, “Islam’s Religious Pluralism in Context”, Islam, 715.

*Corresponding author: Galym Zhussipbek, Independent scholar, Almaty, Kazakhstan; Email: galym.zhussipbek@gmail.com Zhanar Nagayeva, Independent scholar, Almaty, Kazakhstan; Email: zhanar.n2012@icloud.com 
interpretations of Islam. Second, the high level of systematic violations of human rights in Muslim-majority countries and Muslim communities around the world is a known fact. ${ }^{3}$ It is even claimed that many conservative Muslims who live in the liberal-democratic Western countries tend to violate the basic human rights of their family members and close siblings. ${ }^{4}$ Third, the perceptions of Muslims regarding intra-Islamic pluralism are also very problematic. For example, the Pew Survey in 2012 indicated that in 32 of the 39 countries surveyed, half or more Muslims (nearly 6 out of 10) believe that there is only one true way to interpret the teachings of Islam, ranging from a high of 78 percent in Egypt to a low of 34 percent in Morocco. ${ }^{5}$ If we cannot talk about the pluralism among Muslims, how can we talk about Islam and pluralism and the compatibility of Islam and human rights in today's world? Not surprisingly, the Muslim-majority countries are characterized by the un-development, or even absence, of inclusive political, economic and social institutions. This is not only a result of discriminatory politics of the incumbent political regimes, but also a reflection of the religiously exclusivist, sectarian, and tribal mind-set of their scholars and societies in general.

This paper is premised on the understanding that Islam as a religion is a social phenomenon, which is neither an ossified nor oversimplified set of rigid teachings. Although there are many "narrow literalist" and "exclusivist perceptions" spread around the world among the Muslims adhering to different madhabs, Islam, being a religion, is open to different interpretations. For example, the Islamic law is, indeed, an actual construction of human activity - it does not descend from heaven ready-made. ${ }^{6}$ The founding jurists were not engaged in the construction of a "divine and eternal" Sharia (but, in fact, local and temporary), as claimed by conservative Muslims. ${ }^{7}$

We contend that a predominant reason for the erosion of pluralism and inability to produce pluralistic Islamic understandings in the Muslim-dominated countries and Muslim communities around the world is, in general, an epistemological crisis of traditionalist conservative Islamic thought and Muslim mind. We argue that to offer solutions to this crisis, there is a need for epistemological reform by which we depict the incorporation of international standards of human rights into the epistemology and methodology of producing Islamic norms, known as usul al-fiqh, ${ }^{8}$ the roots or sources of figh (in a narrow sense, Islamic law). Furthermore, we argue that some key principles of rationalistic Islamic theology, depicted in this paper as Maturidite theology, may pave the way for this kind of reform. What is proposed in this article is not a reform of Islam as such, of its essentials of creed (aqeeda) and worship (ibadat), which sounds very negative in the Muslim context. Rather, it is an attempt to reform the perceptions and minds of Muslims, how and what they interpret Islam, and to offer intra-Islamic ways to find a kind of compatibility between Islam and international standards of human rights and justice.

We use the concept 'rationalistic Islam' to denote specifically a religious school named Maturidism, of whose epistemology became largely lost. Maturidism accepts the use of reason in its epistemology as one of the main pillars. ${ }^{9}$ As a result of confluence of many factors, the concept 'rationalistic' or 'rationalism' in Islamic tradition has become, in our view, wrongly associated, predominantly with Mutazila school, which in fact, turned out to be irrational in some issues, even extremist. ${ }^{10}$ Nevertheless, we do not aim to absolutise the Maturidite dialectical theology, or Maturidite kalam, ${ }^{11}$ as such. Basically, while each theological school has its own internal logic, its teachings are open to different interpretations and evolution. We only intend to show in this marginalized Islamic school a hidden potential to reform the conservative Islamic scholarship

\footnotetext{
3 Abramowitz, "Democracy in Crisis".

4 See, for example, Khan, "What we don’t know about Europe’s Muslim kids".

5 "World's Muslims: Unity and Diversity".

6 Weiss, The Spirit of Islamic Law, 116.

7 An-Naim, "State Responsibility", 182.

8 Usul al-figh is theoretical and philosophical foundation of Islamic law. The foundational sources are the Quran and Sunnah, also ijma (consensus of major Muslim scholars in a specific age about an issue not covered in the Quran or Sunnah), and qiyas (analogy or rule by precedent) (Hallaq, A History of Islamic Legal Theories, 1).

9 Later in this article we will explain that although it is claimed by many Muslim theologians that Asharism has its own brand of rationalism, this school appears to espouse a theological position which is critical, even detrimental to rationalism.

10 See below.

11 In this paper we use the concepts dialectical theology and kalam interchangeably.
} 
and Muslim mind. By and large, this paper tries to answer these interrelated questions: Is it possible to reform the perceptions of Islam by appealing to Islamic tradition? and How do you develop pluralistic, human rights-friendly Islamic discourse by using internal Islamic dynamics?

Despite the abundant literature about human rights and Islam, as well as reform and Islam, little research has touched on the rationalistic Maturidite kalam's role. Particularly, a serious gap of knowledge exists in discussing the potential of Maturidite theology to produce a credible basis for developing human rights in the Islamic context. The fundamental research done by D. Johnston ${ }^{12}$ about the legitimation of a purposive (Maqasid al-Sharia) approach to Islamic law, epistemology and hermeneutics of Muslim theologies for human rights, openly presents the principles of rationalistic Islamic theology. However, D. Johnston depicts these rationalistic principles, needed to advance a purposive approach to Islamic law and develop human rights in Islamic context, as Mu'tazilite principles. ${ }^{13}$ There is only little literature in English about the potential of Maturidism to develop human rights and reform the conservative Muslim mind produced by counter-radicalism organizations, such as the London-based Quilliam Foundation. ${ }^{14}$

The paper proceeds as follows: First, we briefly discuss the relationship between human rights, religion and Islam. Second, we explore the phenomenon of epistemological crisis of conservative Muslim mind and the demise of dynamic Islamic dialectical theology (the science of kalam). Third, we try to answer the questions What kind of reform? and Look to what tradition? Fourth, we briefly dwell on the key features of theologically rationalistic Islam, Maturidite theology. Then we try to conceptualize the potential of Maturidite theology to make epistemological reform by focusing on its two epistemological principles and presenting a tentative historical antecedent from the late Tsarist period, the short-lived Muslim reformist movement called Jadidism.

\section{Human rights, religion and Islam}

As such, human rights is a concept according to which individuals, being human persons, have certain inalienable rights. Specifically, the term human rights refers to the particular conception of freedom and social justice that was articulated in the Universal Declaration of Human Rights (UDHR) of 1948, and defined with more detail in subsequent treaties. However, it is much contested by the advocates of cultural relativity, who agree that it is a "Western idea", and that is not compatible with the norms and values of many non-Western cultures. ${ }^{15}$ In other words, 'a key question in the universality debate is whether the secular Western origins of human rights, as defined by the UDHR, necessarily mean that these rights are not (or cannot be) truly universal'. ${ }^{16}$ Indeed, it seems difficult to talk about constancy and uniformity for all universal values, and many thinkers consider the concept of "universal values" to be confusing and contradictory. ${ }^{17}$ On the other hand, there have been the thinkers who aimed to develop theories of common morality; for example, the Norwegian philosopher Knut Erik Tranøy, who defines common morality as '... the moral ideas and concepts held by most people, whatever their sources, of what is morally good and evil, of moral virtues and vices, of right and wrong in practical life'. ${ }^{18}$

Nonetheless, we assert that there are some fundamentals when it comes to law and legal procedures, which should be accepted as universal for all people. These universal fundamentals are the principles of human rights adopted by international community and enshrined in core international legal documents, to which a great majority of Muslim-majority countries also acceded, at least formally. Consequently, we argue that although the idea of international human rights was initially a distinctly Western liberal project launched after World War II and the achievement of real human rights occurred by shrinking circles of

12 Johnston, “Maqasid al-Sharia”, 163-164.

13 Ibid.

14 See, for example, Deen, “My Reasons for Joining”.

15 Johnston, "Maqasid al-Sharia”, 149.

16 An-Naim, "Islam and Human Rights", 96.

17 See, for example, MacIntyre, Whose Justice?

18 Larsen, How Muftis Think, 2. 
different exclusions, a result of stones thrown by critics and initiatives by and on behalf of victims, ${ }^{19}$ in our days the key feature of this concept is that each one, regardless of origin, beliefs and way of life, should be treated on the basis of her inherent human dignity.

In essence, the human rights are - under the conditions of 'factual pluralism'-the answer to the question of how to achieve a more just world. In the globalizing world, in which different cultures are confronted with each other, histories intersect and territories overlap, human rights have their place. As H. Sandkühler emphasizes it is human rights which make what the philosophers call human's 'being-inthe-world' concrete and global. ${ }^{20}$ However, the human rights notion is not without critique. For example, Rajagopal exposes the hegemonic character of the liberal human rights movement, implying selectivity in the way rights talk and rights work are implemented. ${ }^{21}$ Hopgood divides between upper-case "Human Rights" and lower-case "human rights". He argues that upper-case "Human Rights" - is what has become elitist. It is a global structure of laws, courts, norms, and organizations that raise money, write reports run campaigns, lobby governments, and claim to speak with singular authority in the name of humanity as a whole. However, lower-case "human rights" is about real people here and everywhere. It is a means, not an end in itself. It's a non-hegemonic language of resistance of (and in the name of) ordinary people against violence, corruption, injustice and for dignity. ${ }^{22}$

As such, there is a paradox of the reality of tension between religion and the notion of human rights, on the one hand, and the importance of reconciliation on the other. ${ }^{23}$ This paradox has generated a vast literature about religion and human rights, and more specifically, about the compatibility of Islam and human rights. Much Muslim writing on the question Is there a conception of human rights in Islam? is hopelessly apologetic, struggling to prove that it is Islam that introduced human rights into the human vocabulary roughly a millennium before Western theorists discovered or even appropriated the idea. However, much Western writing, in turn, is highly contentious, suggesting that the language of human rights is fundamentally alien to Islam. ${ }^{24}$ Nonetheless, we cannot overlook the fact that the literalist readings of Islam emphasize the gaps between the limits of tolerance and acceptability in the Quran and Hadith on the one hand, and internationally-sanctioned standards for human rights on the other. ${ }^{25}$

The issue of Islam and human rights has become much more important in the face of the failure of the very much appreciated "Turkish Islam" model. The failure of both so-called "Turkish Political Islam" ${ }^{26}$ and "Turkish civic Islam" ${ }^{27}$ is very revealing in showing the importance of epistemological reform of conservative Muslim mind. By and large, contrary to previous expectations, the Turkish Muslim politicians, community and religious leaders could not prove that they would remain faithful to the Islamic heritage of Turkey without violating the rule of law and democratic principles. A significant part of the literature about Islam and human rights has been written before this apparent failure. As such, the fiasco of theTurkish model shows the deadlock, specifically, of conservative Sunni, and, in general, the conservative Muslim mind.

On the whole, according to A. An-Naim, the universality of the modern notion of human rights cannot be realized among believers unless they accept it as consistent with their religious beliefs. Despite its clearly secular Western origins, the notion of human rights necessitates religious, namely Islamic, legitimation, and 'this process of religious legitimation requires creative approaches to theological questions' ${ }^{28}$ Therefore, instead of perceiving the relationship between religion and human rights as one of permanent antagonism, it's

19 Falk, Achieving Human Rights, 2-3.

20 Sandkühler, "Pluralism and the Universality of Rights".

21 Rajagopal, "Counter-Hegemonic International Law”.

22 Hopgood, The Endtimes of Human Rights.

23 An-Naim, "Islam and Human Rights", 95.

24 Hashmi, "Islamic Ethics in International Society", 163-4.

25 Akbarzadeh and MacQueen, "Framing the debate on Islam”, 1.

26 See, for example, Oktem and Akkoyunlu, "Exit from democracy”; Esen and Gumuscu, "Rising competitive authoritarianism in Turkey".

27 See, for example, Bacik, "The Intellectual Crisis".

28 An-Naim, "Islam and Human Rights”, 100. 
needed to see this relationship in terms of synergy and mutual influence. ${ }^{29}$ An increasing number of Muslim thinkers have tried to move away from ideological rigidity, emphasizing instead the essence and core human rights values embedded in Islamic sources. ${ }^{30}$ On the other hand, religions, including Islam, need human rights ideology. As Henkin emphasizes, at the least, every religion relies on human rights for freedom of thought, conscience, and for toleration and tolerance, to protect against arbitrary, abusive political power, and they need international human rights law to secure that protection. ${ }^{31}$ Lastly, the phenomenon of "ex-Muslims", the increasing number of young Muslims who have decided to leave Islam because of their disenchantment with traditionalist conservative interpretations, ${ }^{32}$ shows that Islam needs human rights ideology.

\section{Epistemological crisis and demise of Islamic dialectical theology}

Although it is of utmost importance for the Muslims, particularly the scholars, to critically review their understandings of Islam in light of the conditions and requirements of our age, the religious views of mainstream conservative Muslim scholars and those around the world remain largely pre-modern, if not retrograde and obscurantistic. This is exemplified by the demand for, or at least justification of, the death penalty and corporal punishments, not only for crimes and wrongdoings, but also for the issues related to freedom of choice, freedom of thought and expression, issues concerning private life, gender equality and the rights of children. We argue that one of the main reasons for this phenomenon is epistemological crisis of traditionalist conservative Islamic scholarship and conservative Muslim mind. On the other hand, this epistemological crisis is exemplified by seriously insufficient level of protection of human rights under Sharia when judged by contemporary principles of human rights. ${ }^{33}$

As V. Cornell indicates, especially in the Sunni Islamic world, a denial of the autonomy of human reason, a concomitant belief that ultimate truth is accessible to the human being only through divine guidance, and Sharia fundamentalism can be observed. ${ }^{34} \mathrm{M}$. Kamali notices that 'the conventional methodology of usul, which merits attention, is its emphasis on literalism and certain neglect, in some instances at least, of the basic objective and the rationale of the law'. ${ }^{35}$ This denial of rationalism and anti-rationalism has appeared especially as a response to the challenges posed to Islamic thought by modernity, and it is an important signpost of epistemological crisis. ${ }^{36}$ A. MacIntyre explains that at any point epistemological crisis may happen to any tradition-constituted enquiry that, by its own standards of progress, it ceases to make progress. ${ }^{37}$ In other words, epistemological crisis occurs when dynamic processes of development and adaptation of a particular tradition to transforming realities of life has become in some way stymied. ${ }^{38}$

The roots of the epistemological crisis, specifically in the Sunni-Muslim world, can be traced back to as early as the 10th century. By the 10th century, while pure traditionalism submitted to the forms of reason-based jurisprudence (ray school), the jurisprudence schools, including the most reason-based Hanafi school, which epitomized the ray school, submitted to the forms of hadith.$^{39}$ However, as Leaman indicates, it does not mean that the scholars known as "traditionalists" favored irrationality, or that "rationalists" did not use the hadith; it was more a matter of emphasis than a difference in kind. ${ }^{40}$ Nonetheless, this situation can be presented as the eventual victory of traditionalists, which meant that for the entire Sunni-Muslim world, a role for reason in mainstream Sunni Islam became confined within strict limits and mostly in relation to secondary issues

29 Ibid., 95.

30 Akbarzadeh and MacQueen, "Framing the debate on Islam", 3.

31 Henkin, "Establishment” of Religion”, 102.

32 See, for example, “Ex-Muslims”.

33 See for example, An-Naim, "Islam and Human Rights", 98.

34 Cornell, "Reasons Public and Divine”, 26.

35 Kamali, "Methodological Issues", 5.

36 Cornell, "Reasons Public and Divine”, 26.

37 MacIntyre, Whose Justice?, 361-362.

38 Porter, "Tradition in the Recent Work", 47.

39 Melchert, The Formation of, 31.

40 Leaman, “The developed kalam tradition”, 81. 
of jurisprudence. ${ }^{41}$ Specifically, the reasons of epistemological crisis and intellectual stagnation and poverty, fortification of anti-rational scripturalism and the "unthinkable" in Islamic thought can be sought in the demise of dynamic ilm al-kalam (or kalam), the science of rationalistic discursive and dialectical theology.42

On the other hand there is a nexus between the rise of conservative Sunni traditionalism and political developments. In this vein it is of utmost importance that the Seljuqs' initial hostile attitude towards Asharism was radically changed with the Grand Vizier Nizam al-Mulk who eventually became a patron of Asharism and founded a series of madrasas to promote Ashari teachings. The prominent Ashari scholars such as Al-Ghazali, Al-Juwayni, Al-Furaki taught at these madrasas under the patronage of Seljuqs. ${ }^{43}$ Also, it was not a coincident that the ruling dynasties even in the Hanafi-dominant territories went on to promote Asharism and marginalise Maturidism, since the former (particularly the scholars of later generations) appeared lenient towards monarchical and dynastic power, even despotic one. However, the latter was characterised by its prioritization of justice, namely critical attitude toward monarchial power (it was narrated that Al-Maturidi issued a fatwa stating that any scholar found to be in support of a tyrannical, unjust ruler should be excommunicated)..$^{44}$ For example, the Ottomans gradually marginalised Maturidism, whereas they remained Hanafite in jurisprudence, in favour of Asharism after the consolidation of monarchial rule..$^{45}$

The defining characteristic of kalam is its reliance on rational argument of what might be regarded as a dialectical type. ${ }^{46}$ But there often exists no clear-cut distinction between kalam and the other Islamic sciences, such as jurisprudence, philosophy (falsafa), and Sufism. ${ }^{47}$ Therefore, different translations of kalam have appeared, such as "dialectical discourse", "theology", and so on. The literal meaning of this concept warrants emphasis, however: "speech" or, more broadly, "discourse". Kalam's origin in common speech granted it a natural and spontaneous quality no other Islamic discipline possessed. ${ }^{48}$ The early years of kalam came to be seen as a very free period of thought, as evidenced by the popular slogan 'whoever seeks religion through kalam becomes a heretic'. ${ }^{49} \mathrm{Kalam}$, which began as a discursive practice among scholars, exegetes, dissidents, political activists, poets, and other seekers of knowledge, expressed an intellectual community's efforts to delineate parameters for pressing ethical and metaphysical questions. ${ }^{50}$ By the time of Al-Ghazali in the 12th century, kalam was rivaling or out-stripping falsafa in intellectual eminence. ${ }^{51}$

It is argued that the ascendancy of Asharism, the second Sunni school in creed, which became strongly influenced by the Ahl Al-Hadith discourse in some critical issues, led to the eventual consolidation of traditionalism as the dominant school in Sunni Islam and the demise of Islamic rationalism, although the founder and eponym of this school, Al-Ashari, used reason more than leading traditionalist Ibn Hanbal. ${ }^{52}$ Moreover, some authors went as far as to claim that Al-Ashari was not the founder of the way of thinking about kalam, but rather, he was the theological spokesman for a popular movement that had begun nearly a century earlier in Baghdad with Ibn Hanbal. ${ }^{53}$ In other words, increasing incorporation and institutionalization of the forms of Asharism and more traditionalist approaches, like that of Ibn Hanbal teachings, stopped relative freedom of discussion of the early years. ${ }^{54}$

On the whole, the victory of the traditionalists eventually created the situation that while the mainstream Sunni Islam acknowledges that it allocates a role for reason in finding answers to various questions faced by the Muslims, it turned out in fact to do so within the strict limits and mostly in relation to secondary issues

41 Hunter, "Introduction", 25.

42 Halverson, Theology and Creed, 1.

43 Thiele, "Between Cordoba and Nisapur", 234.

44 Kuegelgen and Muminov, Maturidi Doneminde, 284.

45 Ugur, "Roots of Turkish Islam”, 301.

46 Leaman, "The developed kalam tradition", 78.

47 Ibid., 77.

48 Nusseibeh, The story of reason, 25, 60.

49 Leaman, "The developed kalam tradition", 81.

50 Nusseibeh, The story of reason, 60.

51 Leaman, “The developed kalam tradition", 77.

52 Hunter, "Introduction”, 24-25.

53 Martin and Barzegar, "Formations of Orthodoxy”, 189; Madelung, “The Vigilante Movement”, 331-337.

54 Leaman, “The developed kalam tradition”, 81. 
of jurisprudence (fiqh) ${ }^{55}$ Although the doors of Muslim ijtihad (religious reasoning) have always remained open, the Islamic law, in essence, turned out to be 'dead law' in the last centuries. In this atmosphere kalam also fell into steady decline and then into virtual extinction as an active and dynamic science, replaced by a distinctly creedal enterprise. As such the Muslim scholars embarked on favoring legal and scripturalhermeneutic studies to the virtual exclusion of kalam. ${ }^{56}$

Naturally, the religious and political problems not only of Mamluk, but also of later Ottoman periods, contrary to the early Islamic age of dynamic kalam, could only to a small degree be addressed by stagnated and ossified kalam. ${ }^{57}$ By and large, kalam texts became stuck in the traditional paradigms developed centuries ago under different social, political cultural circumstances. In short, kalam in Mamluk and Ottoman madrasas lost its dynamic nature and became of limited usefulness in understanding a changing world..$^{58}$

To conclude, Sunni theology assumes ossified axiomatic forms through a complex confluence of events, including the eventual collapse of the rationalist theological enterprise and virtual extinction of kalam as an active science. ${ }^{59}$ What has become known as kalam, and to which the reformist Muslim thinkers and intellectuals have opposed, was merely a stagnated and ossified form of kalam that lost its dynamic epistemology. However, not only the pressing questions of our age on modernity and Islam, but the fundamental questions such as What are values?, What is Islam and faith?, Who is a Muslim? could be placed in the framework of kalam. ${ }^{60}$ With some rare exceptions, the intellectual poverty has reduced Islamic thought to a pre-modern political and legal tradition. And the extraordinary influence of the idea of Islam as Sharia have made the pre-modern law and ossified legal scholarship the precursor of the state and political life - hundreds of Islamic schools and universities produce thousands of legal scholars but hardly any political theorists or philosophers. ${ }^{61}$ The dynamic development of both Islamism and radical puritanical groups in the last decades is also a direct outcome of the stagnation and demise of the Sunni dialectical theology (or kalam). ${ }^{62}$

The following two phenomena, as it is conceptualized by A. Duderija, both causing and exacerbating the epistemological crisis, ought to be mentioned in this respect: First is the development of hierarchal, legal, and hermeneutical models that are entirely text-based, and the marginalization of non-text-based epistemological and methodological tools of Sunna and Quran, such as ray. Second is hadithification of Sunna, which means that the written hadith-based body of knowledge became Sunna's only vehicle of transmission and embodiment. Naturally, conservative believers may literally refer to sound and written hadiths for direction in life, of which literal meanings may contradict not only contemporary legal standards and norms, but also human reason. ${ }^{63}$

\section{Tradition and reform: the power of forgotten tradition and what kind of reform?}

Concepts like reform, tradition, traditionalism, conservatism, and literalism are highly contested and understood differently by the groups holding different views. What some Muslims may consider as reform others may see as harmful innovation and betrayal of fundamental principles. In addition, even those who believe in the urgent necessity of reforms may differ in the extent and scope of reforms. If some define reform as the reinterpretation of fundamental sources, leading to changes in existing laws and making Islam more

55 Hunter, "Introduction”, 24-25.

56 Halverson, Theology and Creed, 1, 5.

57 Berger, "Interpretations of Ash'arism and Maturidism”, 701.

58 Ibid., 701.

59 Halverson, Theology and Creed, 1.

60 Tayob, "Dialectical Theology", 162.

61 Khan, "The Primacy of Political Philosophy”, 63.

62 Halverson, Theology and Creed, 2, 5.

63 Duderija, "Introduction", 3. 
compatible with the requirements of modernity, others, who conversely adhere to a conservative camp and strict literalist views, define reform as the adoption of a literalist reading of sources and the restoration and maintenance of the norms and practices of early Islam. ${ }^{64}$ However, there is a neglected power of tradition in Islam to launch reform of Muslim mind. As S. Haj aptly emphasizes,

By failing to approach Islam on its own terms and by being unable to imagine Islam as inhabiting a modern world, scholars are often led to wrongly conclude that 'fundamentalist' Islamic movements that violently reject Western modernity embody the essence of Islam, whereas Islamic thinkers who seek to redefine a modern Islam are viewed as inevitably borrowing from liberal political thought. ${ }^{65}$

Not surprisingly, reformist Muslims appeal to Islamic tradition, where they look to early Islam and its traditions to validate their views and positions. They also emphasize the need for revitalization and restoration of Islam's true spirit, which according to them has been suffocated by strict ritualistic and narrow legal construct. In the end, reformists aspire to revive Islam's ultimate, but so far forgotten, aim to establish justice, mercy, and respect for human dignity. ${ }^{66}$

Thevoices to reform thesources, epistemology and methodology (usulal-fiqh) of Islamic legal scholarship have become stronger among Muslim intellectuals. In essence, reformist scholars and intellectuals believe that 'the juristic and scholastic articulations of Islam bear the influences of history and time, which may not be integral to its essence and must, therefore, remain open to evolution and reform ${ }^{6}{ }^{67}$ As An-Naim reminds us, the founding jurists of Sharia constructed what they believed to be an appropriate legal and ethical system for their communities in very local terms, and they were not engaged in the construction of a "divine and eternal" Sharia, as claimed by many Muslims today. Likewise, the most authoritative jurists expressed their views as individual theoretical derivations and cautioned against codifying or implementing them as the only valid version of Sharia. ${ }^{68}$

To undertake reform of traditionalist conservative Islamic scholarship and conservative Muslim mind, we argue that it is necessary to launch epistemological reform which, in essence, is transformative reform. Using Hunter's interpretation of transformative reform, we assert that this kind of reform should be broad and fundamental, entailing re-reading the basic Islamic sources in light of new circumstances, the application of modern methodologies derived from the social sciences in addition to traditional methods, and the extensive revision, even abolition, of those Islamic laws which are considered outdated and irrelevant to Muslims' current needs and aspirations. It is not the narrow reform by employing the classic methodologies with the aim of selective approach to changing only some norms ${ }^{69}$ On the whole, by epistemological reform we depict the incorporation of universal principles of fundamental human rights into the epistemology and methodology of producing Islamic norms, known as usul al-fiqh, the roots or sources of fiqh.

We argue that rationalistic epistemology of the Maturidite kalam may generate a potential for this kind of transformative-by-nature epistemological reform, at least, in the Sunni-Hanafi Islamic context. However, it is a matter of fact that as a result of the eventual collapse of the dynamic kalam, the Maturidite epistemology became largely forgotten. Therefore, we think that it is needed to differentiate between the Maturidite epistemology or dynamic science of Maturidite kalam premised on rationalistic epistemology, which can be tentatively called "software", and Maturidite creed, which tends to be presented by conservative Hanafi Muslims as fortified and dogmatic, tentatively named "hardware". In other words, although the Maturidite creed was not lost and could have been preserved for centuries, Maturidite kalam turned out to be a strictly dogmatic and ossified teaching. It naturally follows that, for example, in Central Asia, the birthplace and historical stronghold (namely, in Bukharan and Samarqandian madrasas), Maturidism turned out to be known as scholastic religious dogmas, whereas its epistemology practically disappeared. Although

64 Hunter, "Introduction", 4.

65 Haj, Reconfiguring Islamic Tradition, 5-6.

66 Hunter, "Introduction", 23.

67 Kamali, "Islam and rights”, 1.

68 An-Naim, "State Responsibility”, 182-183.

69 Hunter, "Introduction", 3. 
some recent research ${ }^{70}$ has shown that the Ashari-Maturidi debates were also a later Ottoman intellectual movement whereby Ottoman-Maturidi scholars embarked on challenging the dominant positions of Asharite teachings, the overall situation in Ottoman scholarship could not be influenced seriously. In general, the Ottoman's religious, social and intellectual life could not allow the revival of rationalistic Maturidite theology per se.

Nonetheless, despite its marginalized position and practical disappearance, Maturidite theology could influence some prominent Muslim reformists. For example, Muhammad Abduh, the famous Egyptian reformist scholar, used to take Al-Maturidi's ideas when touching on the doctrine of goodness and badness of actions. ${ }^{71}$ In addition, Abduh seems to accept the position of Al-Maturidi rather than Al-Ghazali on the question of whether good and evil can be known independently of revelation..$^{72}$ In general, the influence of Maturidite rationalism is quite evident in the writings of Abduh. ${ }^{73}$

\section{Key theological characteristics of marginalized Maturidite rationalistic theology}

By comparison with other schools, foremost, those which are non-rationalistic, Maturidite rationalistic theology shows palpable differences in the issues that are crucial in overcoming the epistemological crisis crippling conservative Islamic scholarship and Muslim mind. Also, although the Islamic scholars conventionally proclaim that there is no serious difference on major issues between Maturidism and Asharism (though we tentatively depict the former as "rationalistic Sunni Islam" and the latter as "traditionalist Sunni Islam"), the differences between these two schools in today's world cannot be accepted as mere nuances.

\subsection{Rationalistic epistemology}

Al-Maturidi was the first mutakallim (dialectical theologian) who could systematize and conceptualize through coherent epistemology the intellectual legacy of Abu Hanifa, which was based to a considerable degree on his personal opinions (ray).$^{74}$ In other words, Al-Maturidi provided a solid intellectual foundation for the Hanafite school. ${ }^{75}$ In essence, rationalist orientation became the Hanafi school's distinctive characteristic, as even the Mu tazilats are said to have claimed Abu Hanifa as one of their own. ${ }^{76}$ Naturally, Maturidism was characterized by emphasizing the rationalist basis of Hanafi thought and as Haydar maintains, Al-Maturidi originated a theological system that judiciously employed kalam. ${ }^{77}$ On the whole, the science of kalam in Transoxania did not have the heretical associations it assumed, in varying degrees, in other parts of the Muslim world. But, among leading Hanafi scholars in other regions, the use of kalam had an overly Mutazili association, and non-Mutazilate Hanafis did not engage in it in fear of falling into heresy. ${ }^{78}$

Al-Maturidi's works became known to the academic community very late, and only two of his works survive. His major work Kitab al-Tawhid was discovered by J. Schacht in the Cambridge University Library in $1951 .{ }^{79}$ One of the paradoxes of Islamic history is that, although Maturidi school is theoretically accepted as one of the two Sunni-Islamic schools in kalam, in fact, it has been marginalized for centuries and practically

70 See, for example, Haydar, The Debates Between Ash'arism and Maturidism.

71 Abdallah, The Doctrines of the Maturidite School, 20.

72 Hourani, Arabic Thought, 142.

73 Afsaruddin, The First Muslims, 102.

74 Ibid., 100.

75 Leaman, “The developed kalam tradition”, 86.

76 Afsaruddin, The First Muslims, 100.

77 Haydar, The Debates Between, 209.

78 Ibid., 209, 23.

79 Pessagno, "Irada, Ikhtiyar”, 177. 
overshadowed by Asharism. ${ }^{80}$ Notwithstanding the fact that as a result of Turkish expansion eastern Hanafism and Maturidi theological doctrine were spread in the Middle East, there is evidence suggesting that some of the most intriguing and characteristic elements of Maturidite theology were excluded from the later development of this school. ${ }^{81}$ As Madelung points out, in the $4^{\text {th }}-10^{\text {th }}$ century there were some differences regarding a few theological questions with the Hanafi scholars of Bukhara, who were more strongly influenced by traditionalist, anti-rationalist tendencies. They were mostly harmonized by later Maturidi scholars with compromised solutions. ${ }^{82}$

As early as the 10th century, the reason-based Hanafi school submitted to the forms of hadith-based schools, ${ }^{83}$ where traditionalists' victory forced the more rationalistic schools of Islamic law to incorporate many of the views and positions of the traditionalists, ${ }^{84}$ and eventually marginalized and even buried into oblivion Maturidite rationalistic epistemology. In other words, while Hanafism became strongly influenced by conservative Asharite discourse and Ahl al-Hadith school, kalam was overcome by creedalism and antitheological thought. A role for reason in mainstream Sunni Islam became confined within strict limits and in relation to secondary issues of jurisprudence. ${ }^{85}$

On the whole, Maturidite theology makes considerable use of reason and counts the effects of social phenomena in interpreting religious texts and producing juristic decisions. As U. Rudolph, a leading scholar of Al-Maturidi's legacy, points out in the opening part of Kitab al-Tawhid, the main master-piece of Al-Maturidi, one can detect a note about the importance of rational speculation, which is much more stressed than was usually done by any Sunni thinkers of that period. ${ }^{86}$ In general, the theology espoused by Al-Maturidi attaches great importance to reason in the synthesis of his doctrine.$^{87}$ Concerning humans, Al-Maturidi used the concept of 'a rational mortal being'. It is revealing that Al-Maturidi adopted this philosophical formula of Aristotelian logic without commentary, whereas Al-Ashari explicitly rejected this definition. ${ }^{88}$ In addition, contrary to Asharism, Maturidism holds that everything created by God has its wisdom.

Particularly concerning the Maturidite theology, the prevailing assumptions that reason is subservient to scripture are completely inconsistent and expose a fundamental misunderstanding of this school. ${ }^{89}$ Al-Maturidi takes a position similar to that of Mutazilate but opposite to that of Asharite, holding that human reason is capable of discovering good and evil. As the classic Maturidi scholar Ala al-Din al-Samarqandi states, 'Good and evil may be known by the intellect according to us and the Mutazilates, contrary to the Ahl al-Hadith'. ${ }^{90}$ On the basis of his rationalist epistemology Al-Maturidi, on some crucial points, is close to the Mutazila and stands generally between the Mutazilats and Asharites. ${ }^{91}$ In particular, the early presentations of Maturidis had positioned themselves together with Mutazilates on one side and Asharites on the other. However, much later presentations of the Maturidite theology positioned themselves in the middle of the Mutazilate and Asharite doctrines. ${ }^{92}$ Overall, Maturidis would agree with the Mutazilas on some critical issues, including that things are intrinsically good or bad and that God takes into consideration these values in His command and prohibition. ${ }^{93}$

Contrary to literalist and dogmatic scholars, Al-Maturidi believes that human reason and perceptions are reliable means of accessing the truth of things in the world, but are necessarily limited. ${ }^{94}$ Even though

80 Abdallah, The Doctrines, 7.

81 Dorroll, "The Universe in Flux“, 119.

82 Madelung, "Maturidism”, 847.

83 Melchert, The Formation of, 31.

84 Hunter, "Introduction”, 25; Melchert The Formation of, 32-38.

85 Hunter, "Introduction", 25.

86 Rudolph, Al-Maturidi, 289.

87 Shah, "Predestination", 640.

88 Rudolph, Al-Maturidi, 300-301.

89 Deen, "A Response to Claims".

90 Ibid.

91 Rahman, Revival and Reform, 62.

92 Deen, "A Response".

93 Ali, "Maturidism", 265.

94 Dorroll, “The Universe in Flux”, 119. 
Maturidite rationalists maintain that reason cannot be the final authority for human obligation and religious law, and they cannot be qualified as "pure rationalists", nevertheless, according to Maturidite theology, reason is the most important of all other sources of knowledge. Similarly, it would be wrong to portray the Mutazilates as "free thinkers" or "pure rationalists", as they confined their understanding of reason in terms of its relation to revelation. ${ }^{95}$ Basically, without reason's assistance, sense and report (revelation) can give no real knowledge. Al-Maturidi points out many cases where nothing but reason can reveal the truth. ${ }^{96}$ For example, when Maturidi scholars were faced with a "problematic" hadith they would override its authority since it was at odds with reason..$^{97}$

As it has been mentioned, we argue that the concept rationalistic or rationalism in Islamic tradition predominantly has become wrongly associated with Mutazila school, which, in some issues may adopt irrational, even extremist views. For example, this school of thought is similar to some radical groups holding that deeds are themselves acts of faith. The implications of this interpretation turned out to be considerable, including the belief that committing a grave sin results in the loss of one's status both as a mumin (a pious Muslim) and as a muslim (believer). For example, according to the view held by the radical Kharijite sect, any Muslim, who commits a grave sin, ceases to be a Muslim, and must be considered apostate, destined for Hell, even justifiably killed. ${ }^{98}$ As S. Haj indicates: 'There is an irony in this, as the Mutazila sect is greatly admired by Western scholarship for its 'rationalism', not its 'extremism' which is clearly displayed in this position, for the implications of it are grave once it is translated into practice - as grave, one might perhaps add, as what Ibn Abdul Wahhab and his so-called contemporary followers have been accused of'. ${ }^{99}$

\subsection{The distinction between faith and deeds, the grounding of God's commands and views on predestination}

In contrast to other Islamic schools, according to Al-Maturidi's doctrine there is no increase or decrease in belief, but only degrees of certainty and affirmation. ${ }^{100}$ Hanafite jurists, basing themselves largely on Al-Maturidi's work, argued that belief does not genuinely increase or decrease, does not depend on action, and can survive sin. Even the worst sinner cannot be treated as an unbeliever, and the decision as to whether he or she is really a believer should be left to God. ${ }^{101}$ As such, Maturidite theology, suggesting a clear division between faith and deeds, provides an effective arena for further debate, since on this rather relaxed criterion for membership of the religious community a good deal of backsliding can be tolerated. ${ }^{102}$ According to Al-Maturidi the foundation of belief consisted only in conviction in the heart. ${ }^{103}$ What is important is that Al-Maturidi advocates an assent that is provided by rational argument and personal conviction. And faith, therefore, in Al-Maturidi's picture, is a process, rather than a destination. ${ }^{104}$ Overall, it can be claimed that Al-Maturidi advocated subjectivity of faith, which is an individual, neither communal nor representative, assent to God. ${ }^{105} \mathrm{Al}$-Maturidi noted that belief is impossible in the presence of force since it is an act of heart and knowledge. ${ }^{106}$ However, enforcement cannot positively affect this kind of act. In the case of forced action, the agent's reason is ignored or overridden by some external agency, with the

95 Haj, Reconfiguring, 240.

96 Ali, "Maturidism", 263.

97 Deen, "My Reasons for Joining".

98 Izutsu, God and Man, 51.

99 Haj, Reconfiguring, 222, note 36.

100 En-Nesefi, Bahr'ul Kelam, 65-66.

101 Leaman, "The developed kalam tradition", 86.

102 Ibid., 86, 89.

103 Al-Maturidi, Kitabu't-Tawhid, 519.

104 Basaran, "The Idea of Subjective Faith, 54.

105 Ibid., 48.

106 Al-Maturidi, Kitabu’t-Tawhid, 480, 492. 
result that what is done cannot be said to have been "chosen". He also strongly objected to the practice of blindly following another's authority in matters of religion (taqlid). ${ }^{107}$

According to G. Hourani, the traditionalist Sunni scholars by whom the followers of Al-Ashari are implied, respecting the omnipotence of God rejected the view (held by both Maturdite and Mutazilate doctrines) that there are objective standards of good and evil which God follows. ${ }^{108}$ Traditionalists hold that the only standard of value for God and man is the will of God. Whatever He wills is good by definition. Based on this principle of "ethical voluntarism", traditionalist scholars claim that God's will suffers no ethical limits. As G. Hourani explains this is "ethical voluntarism", "which after the jurist Al-Shafii became the first principle of Islamic law in most schools ${ }^{109}$ However, both Maturidite and Mutazilate doctrines accept the existence of objective standards of good and evil which God follows. Even though the Mutazilates were careful to argue that God follows these standards freely, their very existence was rejected by traditionalists because they would be both independent and prior to God's will. ${ }^{110}$ In other words, Maturidites and Mutazilates both accept that the bases of the God's commands are an objective standard, not merely based on God's will as the Asharites believe. ${ }^{111} \mathrm{D}$. Johnston depicts the phenomenon that 'God observes standards of justice and goodness, because they exist in and of themselves', in discussing Mutazilate school as "ethical objectivism". ${ }^{112}$ In fact, the Maturidite and Mutazilate teachings have more in common with one another in terms of the grounding of God's commands. In this respect, Maturidite and Mutazilate doctrines support the same epistemological position. ${ }^{113}$ In essence, the Maturidite theology believes that there cannot ever be a contradiction and basic incompatibility between sound reason and scripture, since they both operate within the same ethical sphere and are in harmony. ${ }^{114}$

On the whole, although both Asharite and Maturidite doctrines believe that humans are responsible for their actions through a form of acquisition, which is called kasb (acquisition) by the former school and ikhtiyar (choice) by the latter, ${ }^{115}$ these notions may lead to substantial differences in individual and social life. In the question of free will and determinism, the Maturidites affirmed the doctrine of $k a s b$ that allotted human beings greater power and responsibility for their choices than that granted by the Asharites. Madelung has concisely explained '[For Al-Maturidi] the initial choice is man's, not God's as for al-Ashari'. ${ }^{116}$ In other words, Al-Ashari denied that a human being is an actor in a real sense, ${ }^{117}$ and this view can be regarded as excessively deterministic in substance. ${ }^{118} \mathrm{Al}$-Ashari's reflections on human acts departed from a supposition he shared with the traditionalists. We argue that for the notion of Islamic rationalism, Asharite 'line of reasoning makes nonsense of the fundamental idea that man is individually responsible for his acts'. ${ }^{119}$

\subsection{Two principles of Maturidite rationalistic theology and epistemological reform}

A reformist scholar A. An-Naim reminds that, contrary to the claims of conservative Muslims, the founding Muslim jurists did not construct a non-changeable divine and eternal Sharia, ${ }^{120}$ which, in fact, is a construction of human activity. ${ }^{121}$ As such, the Sharia (figh) is a product of the interaction between the

\footnotetext{
107 Pessagno "Irada, Ikhtiyar”, 181.

108 Hourani, Reason and Tradition, 8.

109 Ibid., 8.

110 Ibid.

111 Deen, "A Response to".

112 Johnston, “Maqasid al-Shari’a”, 163.

113 Deen, "A Response to".

114 Ibid.

115 Lucas, Sunni Theological Schools, 809.

116 Halverson, Theology and Creed, 27.

117 Stefon, Islamic Beliefs, 138.

118 Shah, "Predestination", 640.

119 Thiele, "Between Cordoba and Nisapur”, 228.

120 An-Naim, “State Responsibility”, 182.

121 Weiss, The Spirit of Islamic Law, 116.
} 
Islamic scholars and the social context in which they lived and worked, and its legal formal stipulations are local and temporal in nature. ${ }^{122}$ It can be argued that Al-Maturidi also defended the view that Sharia should be seen as a changeable, socially constructed phenomenon. A Turkish scholar of Maturidite theology H. Ozcan maintains that Al-Maturidi based his understanding of religious tradition (which, inter alia, incorporates Sharia) upon the epistemological grounds that allow for its constant renewal, whereas the essentials and fundamental principles of religion are not seen to be subject to transformation. ${ }^{123}$

In general, we can see the importance of rationalistic principles of Maturidite kalam in showing that reason and faith are not mutually exclusive and in presenting the claims to make pro-human rights reforms in Islamic scholarship. ${ }^{124}$ Specifically, we argue that the following two principles of Maturidite theology can be employed to pave the way for the incorporation of the international standards of human rights into usul al-fiqh, by which we mean epistemological reform: First is acceptance that human reason can find goodness and badness independently from revelation. Second is non-acceptance of "ethical voluntarism", or rather acceptance of "ethical objectivism", the belief that God does not order to do what is known by reason as miserly and ugly. These principles, although depicted as Mutazilate, were touched upon by D. Johnston to legitimate a purposive approach to Islamic law and develop human rights. ${ }^{125}$ In essence, these two principles reflect the two sides of rationalistic Maturidite understanding holding that there can be no conflict between reason and revelation, if the real purport of the latter be correctly understood. ${ }^{126}$

Based on what we name the first rationalistic principle of Maturidism holding that human reason, unaided by scripture, can arrive at what is morally right and wrong, ${ }^{127}$ we argue that the Muslim mind can accept and embrace the notions and values which are not openly stated in Quran and Sunnah, but which have become common achievements of humankind, and not only of the West. Fundamental human rights, such as gender equality, the unreserved acceptance of the right of individual choice and the notions of democracy and secular state can be named in this regard. In other words, by invoking this Maturidite theological principle, we can claim that these values and notions are not alien to Islam. Furthermore, they may be seen, at least tentatively, as "Islamic values", to which humankind has come as a result of its moral, intellectual and legal development. In our days a majority of conservative Muslims tend to reject and even denounce the above-mentioned values and notions as being 'non-Islamic' simply by arguing, in accordance with the conservative non-rationalistic position, that Quran and Sunnah do not openly say about them.

By invoking what we name the second rationalistic principle of Maturidism saying that it is inconceivable in the Maturidite logic that God could order things untruthful and miserly as being good nor anything which is known by the intellect to be wrong (this rationalistic principle puts Maturidite and Asharite positions in fundamental disagreement with one another in terms of their understanding of morality ${ }^{128}$ ), the pre-modern and retrograde religious interpretations of conservative Islamic scholarship can be critically approached and reassessed. In other words, all Islamic norms and interpretations ranging from legitimizing the death penalty and corporal ( $h u d u d$ ) punishments, or rejection of the freedom of changing religion, discrimination based on religious convictions and practice, ${ }^{129}$ to legitimizing the marriage with underage girls, or polygamy, or normalization of the systematic violations of gender equality should be reinterpreted in light of the contemporary human rights values. ${ }^{130}$

122 Alfitri, “Women’s Rights”, 36.

123 Ozcan, "Maturidi'ye Gore”, 77.

124 Early Islamic scholars of Hanafi-Maturidite doctrine had kept a rationalistic and ethical spirit alive until their influence was lost (Deen, "My Reasons of Joining”).

125 Johnston, "Maqasid al-Sharia”, 163-164.

126 Ali, "Maturidism”, 264.

127 In other words, human reason is able to discern right from wrong.

128 Deen, "A Response to".

129 See for example Deen, "My Reasons for".

130 As such the great majority of reasonable people around the world regards the principles such as the sanctity and protection of life, safety, freedom of choice, freedom of thought and expression, upholding justice and equality before the law (regardless of the origin and beliefs), gender equality as universal principles and basic standards of justice. Likewise, the acts such as killing a person only because of adherence to a different view or pursing a different lifestyle, violence or discrimination against women and children, crimes like pedophilia are rejected and viewed as unacceptably miserly and ugly and greatly unjust. 
In brief, we think that in the rationalistic Maturidite principles a legitimate mechanism for reinterpretation and change for those Sharia norms and, in general, all religious interpretations that are inconsistent with the international standards of human rights and justice can be found. On the whole, rationalistic Maturidite theology can be presented as a good intra-Islamic mechanism of reforming the Muslim mind through inclusion of contemporary standards of human rights into the epistemology of producing religious norms and interpretations.

Epistemological reform proposed in this paper goes beyond the scopes of the Maqasid al-Sharia approach. The proponents of this approach posit that the primary religious sources of Islam, the Quran and Sunna, should be seen as maqasid-oriented - to look at the general philosophy and objectives of religious injunctions, often beyond the particularities of the text. ${ }^{131}$ Nonetheless, the effectiveness of the theory of Maqasid al-Sharia may be partial at best. As A. Duderija explains, although for contemporary Muslim thinkers such as H. Hanafi, M. Al-Jabiri, and N. Madjid, Maqasid al-Sharia dimensions of Islamic law are seen as the essence of the Qur'an and interpretations founded on these interpretational mechanisms can take precedence over clear Quranic text, they represent minority voices who are too few and came too late to significantly shape the Islamic law. ${ }^{132}$ In short, the impact of the theory of Maqasid al-Sharia in today's world 'in meeting the challenges Muslim reformist thought is responding and seeking to find solutions to' may be limited. ${ }^{133}$ Also, in view of the fact that a number of strictly conservative believers, who defend the corporal punishments like hudud, may also accept some aspects of maqasid, the main aims of religion, for example, as they were formulated by Al-Ghazali, it is important not only what is considered to be the aims of religion, but it is also important the methods to reach these aims. In other words, some conservative believers may defend the methods of achieving the higher aims of Sharia which are in direct contradiction with today's legal standards and norms.

The epistemological reform we propose can be seen to be more concrete and unambiguous than what is offered by T. Ramadan through the concept "transformation reform” or "Radical Reform”. ${ }^{134}$ One of the key meanings of "Radical Reform" is 'a radical displacement of Law from the center of Islamic normative inquiry and its substitution with a much more elusive conception of 'ethics'. ${ }^{135}$ Instead of proposing to include the ethics into the essentials of producing Islamic norms, which is a contested and very ambiguous concept, we propose to include well-established universal principles of human rights adopted by the international community and enshrined in international legal documents. Although, the concept "Radical Reform" urges for full equality between scholars of the texts and the natural world as equal ulama in producing fatwas, ${ }^{136}$ however, this idea is proposed without clear-cut Islamic epistemological grounding, which can be provided by Maturidite rationalism holding that human reason can find goodness and badness independent from revelation.

\subsection{Jadidism as a tentative historical antecedent of epistemological reform}

To show the potential of rationalistic Maturidite principles to make epistemological reform, we want to draw attention to the short-lived Muslim reformist movement called Jadidism ${ }^{137}$ (Jadid literally means "new")

131 Kamali, "Maqasid”, 5.

132 Duderija, “Contemporary Muslim”, 5.

133 Ibid., 2.

134 Ramadan, Radical Reform.

135 March, “The Post-Legal Ethics”, 254.

136 Warren, "Doha - The Center of", 151.

137 At the very beginning, Jadidism emerged as educational reformist movement; Jadid intellectuals established and promoted, instead of old scholastic and punitive methods, the new method (usul-u Jadid) in teaching children. However, Jadid reform was implemented with a great variety of applications, which can hardly be summarized under the common denomination of Jadidism, as has been done by many modern historians. As such, the reformed madrasas of were accused by the conservative ulama of being mere schools of philosophy and literature, if not instruments of cultural Europeanization (Dudoignon, "Echoes to Al-Manar", 90, 94). 
emerged in the late Tsarist period, whose prominent members adhered to Maturidism and tried to revive Islamic rationalism. As such, the literature on Muslim rationalism, democracy and modernism takes little account of the experience of the Muslims who inhabited the Russian Empire and the early Soviet period. ${ }^{138}$ The Jadid intellectuals attempted to reconcile Islam with modernity. They believed that the Muslims have to acquire modern knowledge and reform their understanding of Islam. ${ }^{139}$ Jadidism represented the first proliberal (in political and social terms) and rationalistic (in Islamic theological terms) reformist movement among the Eurasian Muslims. Jadids believed that the juristic and scholastic articulations of Islam must be open to evolution and reform. Although many Jadids were devoted Muslims, they were against polygamy and defended the legal equality between men and women. They defended creation of the secular state. It's revealing that the First Muslim Congress held under the leadership of Jadids in 1917 declared the political equality of genders, the overall education of girls, active participation of Muslim women in public life and prohibited polygamy. ${ }^{140}$ When the 1917 February Revolution created favorable conditions and the Jadids could seize power from their conservative counterparts in Orenburg Muslim Administration they could elect a female qadi (a Muslim judge) to the Central Spiritual Administration and issued a fatwa declaring that Sharia allowed women to assume political office. ${ }^{141}$

The works of Musa Jarullah Bigiev (1875-1941), ${ }^{142}$ a prominent Russian-Tatar reformist Hanafi-Maturidite scholar ${ }^{143}$ bear the deep imprint of the rationalistic approach to Islam. For Musa Jarullah, human reason cannot be limited ${ }^{144}$ and he was referred as reformist mutakallim, dialectical theologian. ${ }^{145}$ Musa Jarullah, by raising the questions of dynamic, "deep kalam", such as What is Islam in new age?, What is to be a Muslim in modern times?, and meanwhile condemning the dogmatic "ossified kalam", attempted to develop not only inclusive Islamic interpretations ${ }^{146}$ but also human-centric understandings of Islam. For example, according to his rationalistic and human-centric epistemology, Islam is everything that the believer does in bringing goodness to people and to make the life of people happy, safe and comfortable. Bigiev defended a new approach to fiqh, where it has to become "human-needs- centric". ${ }^{147}$ The last Ottoman Shaikh-ul Islam, despite the ongoing war and the collapse of the state, banned Bigiev's key treatise because of the author's rationalistic approach to some key theological and juristic issues. In that time Bigiev's rationalistic approach was considered by conservative Hanafi ulama to be heretical and as dangerous as the collapse of the Caliphate.

Another Jadid scholar, Gumar Karash, who lived in Kazakh Inner Horde and played a considerable role in social and political life in that region, adopted a rationalistic methodology and produced a number of fatwas that caused strong backlash from the conservative ulama. For example, Karash argued against the animal sacrificing during Eid Al-Adha and instead proposed to donate to charity. He also argued against the ritual male circumcision. ${ }^{148}$

\section{Conclusion}

Today many Muslims around the world are encountering the question of how to reconcile religious adherence with a commitment to the universality of human rights. As A. An-Naim emphasizes, it is a fact

138 Khalid, "Being Muslim”, 123-124.

139 Khalid, The Politics.

140 Daulet, "The first all Muslim”, 25.

141 Garipova, "Muslim Female”, 136, 139.

142 Although Bigiev, who was a pupil of Abduh at al-Azhar, was well-known to his contemporaries, both admired and despised by many, his intellectual legacy became largely lost and is almost unknown in today's Western academia and in Muslim world.

143 Bigi, Uzun Günlerde, 35; Suyargulov, “Musa Carullah’in”, 209.

144 Bigi, Uzun Günlerde, 192; Suyargulov, “Musa Carullah’in”, 209.

145 Dudoignon, "Echoes to Al-Manar”, 89.

146 Based on rationalistic premises Bigiev developed his teachings about God's all-inclusive forgiveness, in other words, according to him non-Muslims will also be saved in the Hereafter.

147 Khayrutdinov, "Bigiev on the”, 78-80.

148 Shabley, "Fatwas of Akhun Gumar”, 18-20. 
that the level of protection of rights under Sharia is not sufficient when judged by the standards set by the UDHR, which require equal rights for all human beings, without distinction on such grounds as sex, religion, or belief. ${ }^{149}$ In addition, there is a desire to see Islamic teachings open to the changes in intellectual and scientific development of humanity and transformations in social life. ${ }^{150}$ Nonetheless, because of the epistemological crisis of Islamic scholarship, manifested, inter alia, in the centuries-long demise of kalam as a dynamic science, the pressing ethical and metaphysical questions concerning the necessity of producing human rights-friendly Islamic interpretations became largely unthinkable in conservative Muslim circles. Furthermore, literalism, resistance to use of reason in interpretation of religious sources (Quran and Hadith) and invocation of bila kayf ("without asking why and how") principle has become normalized. However, all norms and concepts of Sharia contradicting international human rights standards are the products of human understanding developed in specific historical context, and in no way are direct divine decrees expected to be applied forever. ${ }^{151}$ And continuing in the way of hard-line conservatism will only harm the long term future of Islam as a universal religion.

Given the human-made nature of Sharia, it is indeed imperative for modern Muslim scholars to construct an Islamic legal and ethical system that is appropriate for the present historical context of Muslim societies ${ }^{152}$ which is marked by globalization and development of human rights. Likewise, the universality of human rights must be realized through the implementation of deliberate strategies of religious legitimation. ${ }^{153}$

We argue that through employing the rationalistic principles of Maturidite kalam, first, the common achievements of humankind, namely the notions of fundamental human rights, democracy, gender equality, the right of individual choice, may be seen as not alien to Islam. Second, pre-modern religious interpretations can be critically approached and reinterpreted.

The epistemological reform we propose denotes the incorporation of international standards of human rights and justice into the epistemology and methodology of producing Islamic norms (usul al-fiqh). As such, the epistemological reform undertaken by invoking the forgotten Islamic rationalistic Maturidite tradition may be more welcomed than Islamic modernist ideas. In other words, the appeal to rationalistic principles of Maturdite theology can help a majority of ordinary Muslims who may feel, at least, irritation towards Islamic modernist ideas, that may diverge from the essentials of Islamic creed and worship, ${ }^{154}$ to develop human rights-friendly religious understandings. A majority of Muslims also may not properly perceive the so-called 'Progressive Muslim' discourse, which is still predominantly elitist, spread among Western-educated Muslim intellectuals. ${ }^{155}$

Although A. Macintyre's moral philosophical critique warns that the use of reason never leads to agreement on moral issues, ${ }^{156}$ we think that reason, being the human capacity for shaping reality in a humane way, ${ }^{157}$ is indispensable to read Islamic sources (to borrow the words of Marcus Borg ${ }^{158}$ ), from a historical-metaphorical point of view, which means that the they are taken seriously, without being

149 An-Naim, "Islam and Human Rights", 98.

150 Also it can be argued that the young generations of Muslims would like to see a more egalitarian, pluralistic and inclusive Islam, and Muslim scholars and intellectuals should be aware of this fact.

151 An-Naim, "Islam and Human Rights”, 98.

152 An-Naim, "State Responsibility”, 182-183.

153 An-naim, “Islam and Human Rights”, 100.

154 For example, the ideas of the reformists like M. Shahrur, who does not regard the Sunna as a sacred source of Islamic moral law, may sound bad with a majority of believers. However, M. Shahrur in Maturidite way maintains that a rational definition of faith is not only more truthful to the modern, universal spirit of intellectual thought but also superior to the particularistic and ritualistic religiosity of traditional Islam (Christmann, "Introduction”, xxviii).

155 "Progressive Muslim's" methodology is based on the view that certain Quranic ethicoreligious values, such as justice, dignity of all human beings, equity, mercy, and righteous conduct are higher-order principles of interpretation of Islamic injunctions, to which all other norms/values are subservient ( Duderija, "Construction of the Religious, 101).

156 MacIntyre, Whose Justice?

157 Sandkühler, "Pluralism".

158 Borg, Reading the Bible. 
taken literally, ${ }^{159}$ and to make religious doctrines compatible with the international standards of human rights. To sumarize, we argue that, by invoking the rationalistic Islamic theology, the theological grounds to undertake epistemological reform of conservative Islamic scholarship and conservative Muslim mind can be found. Furthermore, it can be seen as a vehicle pushing the Muslims to go beyond fiqh towards the horizons of "post-legal" (using the A. March's conceptualization ${ }^{160}$ ) and building pluralistic and humancentric society of the 21st century.

\section{References}

Abdallah, Umar. "The Doctrines of the Maturidite School with Special Reference to As-Sawad Al-Azam of Al-Hakim As-Samarqandi.” Ph.D. Dissertation, University of Edinburgh, 1974.

Afsaruddin, Asma. The First Muslims. History and Memory. Oxford: One World, 2007.

Akbarzadeh Shahram and Benjamin MacQueen, "Framing the debate on Islam and human rights." In Islam and Human Rights in Practice, edited by Shahram Akbarzadeh and Benjamin MacQueen. NY: Routledge, 2008.

Al-Maturidi. Kitabut-Tawhid (in Turkish), translated by Bekir Topaloglu. Ankara: ISAM, 2009.

Alfitri, Alfitri. “Women's Rights And Gender Equality Issues in Islamic Law in Indonesia: The need to re-read Women's Status in the Islamic Religious Texts."Mazahib, 13: 1, 2014.

Ali, Ayyub. "Maturidism." In A History of Muslim Philosophy, edited by M. Sharif. Weisbaden: Otto Harrassowitz, 1963.

An-Naim, Abdallahi. "State Responsibility Under International Human Rights Law to Change Religious and Customary Laws." In Human Rights of Women. National and International Perspectives, edited by R. Cook. Philadelphia: University of Pennsylvania Press, 1994.

An-Naim, Abdallahi. "Islam and Human Rights: Beyond the Universality Debate.” Proceedings of the Annual Meeting, American Society of International Law, 2000.

Bacik Gokhan, “The Intellectual Crisis of the Gülen Movement.” Ahvalnews (May 16, 2018). https://ahvalnews.com/gulenmovement/intellectual-crisis-gulen-movement.

Basaran, Yasin. "The Idea of Subjective Faith in al-Maturidi's Theology.”Journal of Islamic Research, 4: 2, 2011.

Berger, Lutz. "Interpretations of Asharism and Maturidism in Mamluk and Ottoman Times." In The Oxford Handbook of Islamic Theology, edited by Sabine Schmidtke. Oxford: Oxford University Press, 2016.

Bigi, Musa Carullah. Uzun Günlerde Oruç: Ictihad Kitabi. Ankara, 1975.

Borg, Marcus. Reading the Bible Again For the First Time. HarperCollins 2001.

Christmann, Andreas. “Introduction." In The Quran, Morality and Critical Reason. The essential Muhammad Shahrur, edited by Andreas Christmann. Leiden: Brill, 2009.

Cornell, Vincent. "Reasons Public and Divine: Liberal Democracy, Sharia Fundamentalism, and the Epistemological Crisis of Islam.” In Rethinking Islamic Studies From Orientalism to Cosmopolitanism, edited by Carl Ernst and Richard Martin. University of South Carolina, 2010.

Daulet, Shafiga. “The first all Muslim congress of Russia Moscow 1-11 May 1917.” Central Asian Survey, 8:1, 1989.

Deen, Adam. “My Reasons for Joining the Quilliam Foundation.”Quilliam Foundation, 2015. https://www.quilliaminternational. $\mathrm{com} / \mathrm{my}$-reasons-for-joining-the-quilliam-foundation-adam-deen/.

Deen, Adam. “A Response to Claims of Unorthodoxy of My Theological claims.” Quilliam Foundation, 2016. https://www. quilliaminternational.com/a-response-to-claims-of-unorthodoxy-of-my-theological-claims-within-my-reasons-forjoining-the-quilliam-foundation-piece/.

“Democracy in Crisis.” Freedom House, 2018. https://freedomhouse.org/report/freedom-world/freedom-world-2018.

Dorroll, Philip. "The Universe in Flux: Reconsidering Abu Mansur Al-Maturidi’s Metaphysics and Epistemology." Journal of Islamic Studies, 27: 2, 2016.

Duderija, Adis. "Construction of the Religious Self and the Other: The Progressive Muslims' Manhaj." Studies in Contemporary Islam, 10: 1-2, 2008.

Duderija, Adis. "Contemporary Muslim Reformist Thought and Maqașid cum Maslaḥa Approaches to Islamic Law.” In Maqasid al-Sharia and Contemporary Reformist Muslim Thought, edited by Adis Duderija. NY: Palgrave Macmillan, 2014.

Duderija, Adis, “Introduction." In The Sunna and Its Status in Islamic Law. The Search for a Sound Hadith, edited by Adis Duderija. Palgrave Macmillan, 2015.

Dudoignon, Stephane. "Echoes to Al-Manar among the Muslims of the Russian Empire." In Intellectuals in the Modern Islamic World, edited by Stephane Dudoignon, K. Hisao, K. Yasushi. NY: Routledge 2006.

159 For example, M. Bigiev argued that fasting is not obligatory for the people who live in the areas where days lasts very long (Bigi, Uzun gunlerde, 115). His position is not to declare that some ayats are cancelled, and others are valid, but to understand that they are addressed to different audiences, in a different epoch (Khakimov, "Euro Islam").

160 March, “The Post-Legal Ethics”, 273. 
En-Nesefi, Ebu’l-Muin. Bahr’ul Kelam (Maturidi Creed), translated by Ramazan Bicer. Istanbul: Gelenek, 2010.

Esen Berk and Sebhem Gumuscu, “Rising competitive authoritarianism in Turkey.” Third World Quarterly 37: 9 (2016), 1581-1606.

“Ex-Muslims: They left Islam and now tour the US to talk about it." BBC (November 27, 2017, https://www.bbc.com/news/ world-us-canada-42090104.

Falk, Richard. Achieving Human Rights. NY: Routledge, 2009.

Garipova, Rozaliya. “Muslim Female Religious Authority in Russia: How Mukhlisa Bubi Became the First Female Qadi in the Modern Muslim World."Dei Welt Des Islams, 57: 2, 2017.

Haj, Samira. Reconfiguring Islamic Tradition. Reform, Rationality and Modernity. Stanford: Stanford University Press, 2009.

Hallaq, Wael. A History of Islamic Legal Theories: An Introduction to Sunni usul al-figh. Cambridge: Cambridge University Press, 1997.

Halverson, Jeffry R. Theology and Creed in Sunni Islam, The Muslim Brotherhood, Ash'arism, and Political Sunnism. Palgrave Macmillan, 2010.

Hashmi, Sohail. "Islamic Ethics in International Society.” In Islamic Political Ethics: Civil Society, Pluralism, and Conflict, edited by Sohail Hashmi. Princeton University Press, 2002.

Haydar, Yahya. "The Debates Between Asharism and Maturidism in Ottoman Religious Scholarship: A Historical and Bibliographical Study." Ph.D. Dissertation, Australian National University, 2016.

Henkin, Louis. “Establishment” of Religion and Human Rights: Comment.” Proceedings of the Annual Meeting, American Society of International Law, 2000.

Hopgood, Stephen. The Endtimes of Human Rights. Ithaca: Cornell University Press, 2013.

Hourani, Albert. Arabic Thought in the Liberal Age 1798 - 1939. Cambridge University Press, 1983.

Hourani, George. Reason and Tradition in Islamic Ethics. Cambridge University Press, 2007.

Hunter, Shireen. "Introduction." In Reformist Voices of Islam. Mediating Islam and Modernity, edited Shireen Hunter NY: M.E.Sharpe, 2009.

Johnston, David. "Maqasid al-Sharia: Epistemology and Hermeneutics of Muslim Theologies of Human Rights Author(s)." Die Welt des Islams, New Series, 47:2, 2007.

Izutsu, Toshikiko. God and Man. Islamic Book Trust, 2002.

Kamali, Mohammad H. "Methodological Issues in Islamic Jurisprudence.” Arab Law Quarterly 11: 1, 1996.

Kamali, Mohammad H. “Islam's Religious Pluralism in Context, a Viewpoint." Islam and Civilisational Renewal, 2:4, 2011.

Kamali, Mohammad H. "Maqasid (Higher Objectives) of Shariah.” Institute of Advanced Islamic Studies, Kuala-Lumpur, 2012. https://www.iais.org.my/e/publications-sp-1447159098/dirasat-sp-1862130118/shariah-law-governance-halal/ item/124-maqasid-higher-objectives-of-shariah.

Kamali, Mohammad H. “Islam and rights." The International Institute of Advanced Islamic Studies, 2014. http://www.iais.org my/e/index.php/publications-sp-1447159098/articles/item/216-islam-and-rights.html.

Khakimov, Rafael. “Euro Islam in Volga Region.” Kazan Center of Federalism and Public Policy, 2005. https://www.kazanfed. ru/en/authors/khakimov/publ1/

Khalid, Adeep. "Being Muslim in Soviet Central Asia, or an Alternative History of Muslim Modernity." Journal of the Canadian Historical Association / Revue de la Société historique du Canada 18: 2, 2007.

Khalid, Adeep. The Politics of Muslim Cultural Reform: Jadidism in Central Asia. Oxford University Press 2010.

Khan, Deyyah. "What we don't know about Europe's Muslim kids.” TEDxExeter, April 2016. https://www.ted.com/talks/ deeyah_khan_what_we_don_t_know_about_europe_s_muslim_kids.

Khan, M. Muqtedar. "The Primacy of Political Philosophy." In Islam and the Challenge of Democracy, edited by J. Cohen and D. Chasman. Princeton University Press, 2004.

Khayrutdinov, Aydar. "Bigiev on the Renewal of Muslim Legal System." In Bigiev Symposium: Theological Thought of Russian Muslims in the 19th - early 20th centuries, edited by I. Zaripov and D. Mukhetdinov. Moscow: Medina, 2015.

Kuegelgen, A., \& Muminov, A. “Maturidi Doneminde Semerkant Ilahiyatcilari (Theologians During Al-Maturidi Time)”. In Imam Maturidi ve Maturidilik (Imam Al-Maturidi and Maturidism), edited by S. Kutlu. Ankara: Kitabiyat, 2003.

Larsen, Lena. How Muftis Think, Islamic Legal Thought and Muslim Women in Western Europe. Leiden: Brill, 2018.

Lawrence, Bruce. Shattering the Myth: Islam Beyond Violence. Princeton University Press, 1998.

Leaman, Oliver. "The developed kalam tradition." In The Cambridge companion to classical Islamic theology, edited by Timothy Winter. Cambridge University Press, 2008.

Lucas, Scott. "Sunni Theological Schools." In Medieval Islamic Civilization: An Encyclopedia, vol. 1, edited by Josef W. Meri. NY: Routledge, 2006.

MacIntyre, Alasdair. Whose Justice? Whose Rationality. University of Notre Dame Press, 1988.

Madelung, Wilferd. "The Vigilante Movement of Sahl b. Salama al-Khurasani and the Origins of Hanbalism Reconsidered." Journal of Turkish Studies, 14, 1990.

Madelung, Wilferd. “Maturidism.” In The Encyclopaedia of Islam, edited by P. Bosworth and et.al. Leiden: Brill, 1991.

March, Andrew. "The Post-Legal Ethics of Tariq Ramadan: Persuasion and Performance in Radical Reform: Islamic Ethics and Liberation.” Middle East Law and Governance, 2: 2, 2010. 
Martin Richard and A. Barzegar. "Formations of Orthodoxy. Authority, Power, and Networks in Muslim Societies." In Rethinking Islamic Studies From Orientalism to Cosmopolitanism, edited C. Ernst and R.Martin. University of South Carolina, 2010.

Melchert, Christopher. The Formation of the Sunni Schools of Law, 9th-10th Centuries. Leiden: Brill, 1997.

Nusseibeh, Sari. The story of reason in Islam. Stanford University Press, 2016.

Oktem Kerem and K. Akkoyunlu. "Exit from democracy: illiberal governance in Turkey and beyond." Southeast European and Black Sea Studies 16: 4 (2016), 469-480.

Ozcan, Hanifi. Maturidi'de Dini Cogulculuk. Istanbul: IFAV, 1995.

Ozcan, Hanifi. “Maturidi’ye Gore Din-Seriat Ayiriminin Felsefi Temelleri.” In Buyuk Turk Bilgini Imam Maturidi ve Maturidilik. Istanbul: Marmara University Theology Faculty Publications, 2010.

Pessagno, J. Meric. “Irada, Ikhtiyar, Qudra, Kasb. The View of Abu Mansur Al-Maturidi.” Journal of the American Oriental Society 104: 1, 1984.

Porter, Jean. "Tradition in the Recent Work of Alasdair MacIntyre." In Alasdair MacIntyre, edited by M.Murphy. Cambridge University Press, 2003.

Rahman, Fazlur. Revival and Reform in Islam. Oxford: One World, 2000.

Rajagopal, Balakrishnan. “Counter-Hegemonic International Law: Rethinking Human Rights and Development as a Third World Strategy." Third World Quarterly, 27: 5 (2006).

Ramadan, Tariq. Radical Reform. Islamic Ethics and Liberation. Oxford: Oxford University Press, 2009.

Rudolph, Ulrich. Al-Maturidi and the Development of Sunni Theology in Samarqand, translated by R. Adem. Leiden: Brill, 2015.

Sandkühler, Hans J. "Pluralism and the Universality of Rights." 20th World Congress of Philosophy, 1998. https://www. bu.edu/wcp/Papers/Law/LawSand.htm.

Shabley, Pavel. "Fatwas of Akhun Gumar Karash: Muftiyat and Legal Clashes in the Inner Kazakh Horde at the beginning of the 20th Century." Islamology (Moscow, Mardjani Foundation) 7: 2, 2017.

Shah, Mustafa. "Predestination."In Medieval Islamic Civilization: An Encyclopedia, Vol.1 edited by J. Meri. NY: Routledge, 2006.

Stefon, Matt. Islamic Beliefs and Practices. NY: Britannica Educational, 2010.

Suyargulov, Rifat. “Musa Carullah’in Ilahi Rahmetin Genişliği Hakkındaki Dusuncesinin Degerlendirilmesi.” Dini Araştırmalar 20: 52, 2017.

Tayob, Abdulkader. "Dialectical Theology in the Search for Modern Islam.” In Islamic Studies in the Twenty-first Century, edited. L. Buskens and A. van Sandwijk. Amsterdam University Press, 2016.

Thiele, Jan. "Between Cordoba and Nisapur: The Emergence and Consolidation of Asharism." In The Oxford Handbook of Islamic Theology, edited by Sabine Schmidtke. Oxford: Oxford University Press, 2016.

Ugur, Etga. "Roots of Turkish Islam and Approaches to the Turkish Model." Journal of Muslim Minority Affairs 24:2, 2004.

Warren, David. "Doha - The Center of Reformist Islam? Considering Radical Reform in the Qatar Context: Tariq Ramadan and the Research Center for Islamic Legislation and Ethics." In Maqasid al-Sharia and Contemporary Reformist Muslim Thought, edited by Adis Duderijia. NY: Palgrave, 2014.

Weiss, Bernard. The Spirit of Islamic Law. Athens: University of Georgia Press, 1998.

“World's Muslims: Unity and Diversity.” Pew Research, 2012. https://www.pewforum.org/2012/08/09/the-worlds-muslimsunity-and-diversity-executive-summary/ 